\title{
Problematika Pengintegrasian Penguatan Pendidikan Karakter pada Pembelajaran Tematik
}

\author{
Wilis Wijanarti ${ }^{1}$, I Nyoman Sudana Degeng ${ }^{2}$, Sri Untari ${ }^{3}$ \\ ${ }^{1}$ Pendidikan Dasar-Universitas Negeri Malang \\ ${ }^{2}$ Teknologi Pembelajaran-Universitas Negeri Malang \\ ${ }^{3}$ Pendidikan Pancasila dan Kewarganegaraan-Universitas Negeri Malang
}

\begin{tabular}{l}
\hline \hline INFO ARTIKEL \\
\hline RiwayatArtikel: \\
Diterima: 01-02-2019 \\
Disetujui: 19-03-2019 \\
\hline
\end{tabular}

Kata kunci:

problems in thematic learning character building;

problematika pembelajaran tematik;

pendidikan karakter

\begin{abstract}
ABSTRAK
Abstract: This study aims to describe the problem of integrating the strengthening of character education in thematic learning that discuss the problem of the design of learning implementation, implementation of learning, assessment of learning and solutions. This study used a qualitative descriptive approach with a type of case study research and used the Robert K. Yin data analysis model. The results of this study state that there are problems in making the design of the implementation of learning, the implementation of learning and assessment of learning. It is suggested that the teacher must optimize the planting of characters by cooperating with each other between the school, the community, and the education office to improve deficiencies in the planting of character education in schools.

Abstrak: Penelitian ini bertujuan untuk mendeskripsikan problem pengintegrasian penguatan pendidikan karakter dalam pembelajaran tematik yang membahas tentang masalah rancangan pelaksanaan pembelajaran, pelaksanaan pembelajaran, penilaian pembelajaran dan solusinya. Penelitian ini menggunakan pendekatan deskriptif kualitatif dengan jenis penelitian studi kasus dan menggunakan analisis data model Robert K. Yin. Hasil dari penelitian ini menyatakan terdapat masalah dalam pembuatan rancangan pelaksanaan pembelajaran, pelaksanaan pembelajaran dan penilaian pembelajaran. Disarankan guru harus mengoptimalkan penanaman karakter dengan saling bekerja sama antar pihak sekolah, masyarakat, dan dinas pendidikan guna memperbaiki kekurangan dalam penanaman pendidikan karakter di sekolah.
\end{abstract}

\author{
AlamatKorespondensi: \\ Wilis Wijanarti \\ Pendidikan Dasar \\ Universitas Negeri Malang \\ Jalan Semarang 5 Malang \\ E-mail: wiliswiajanrti26@gmail.com
}

Indonesia saat ini sedang menata kembali sistem pendidikannya tidak hanya memikirkan penguasaan materi atau dalam hal kognitifnya saja, tetapi juga menempatkan Pendidikan karakter sebagai jiwa Pendidikan Nasional. Melalui pendidikan karakter yang tangguh, unggul, dan memiliki kompetensi tinggi dihasilkan oleh pendidikan yang baik maka akan mampu manjawab tantangan dan tuntutan abad XXI. Hal itu sesuai apa yang telah dijelaskan oleh oleh Ki Hajar Dewantara "upaya untuk memajukan bertumbuhannya budi pekerti (kekuatan batin, karakter), pikiran (intelek) dan tubuh anak. Bagian-bagian itu tidak boleh dipisahkan agar dapat memajukan kesempurnaan hidup peserta didik.

Pembelajaran tematik yang berlangsung mengintegrasi nilai-nilai karakter sehingga anak tidak hanya pintar dalam pengetahuan ataupun penguasaan materi saja, tetapi memiliki budi pekerti yang baik. Hal itu juga dijelaskan (Ghufron, 2007; Julaiha, 2014) untuk mengenalkan nilai-nilai baik dapat melalui pengintegrasian ke dalam muatan pembelajaran dan dilaksanakan di dalam kelas pada saat pembelajaraan maupun di luar kelas. Mengintegrasi nilai karakter berarti memasukkan atau memadukan untuk mengembangkan dan membentuk sikap positif ke dalam diri peserta didik.

Pelaksanaan pendidikan karakter dapat dilaksanakan di dalam sekolah maupun di luar sekolah. Lembaga pendidikan menjadi sarana strategis dalam pembentukan karakter bangsa karena memiliki struktur, sistem, dan perangkat yang tersebar di seluruh Indonesia dari Sabang sampai Merauke. Menurut (Johansson, 2011) sekolah merupakan suatu yang memiliki peran penting dalam menyiapkan kecakapan hidup peserta didik, baik secara akademis maupun non akademis. Pendidikan karakter perlu ditanamkan sedini mungkin dan secara terus menerus atau berkelanjutan agar pembentukan atau pengembangan karakter baik dalam diri anak berjalan dengan baik. Hal itu sejalan dengan (Suwandayani, 2017) yang menjelaskan bahwa "pendidikan karakter harus menjadi ajaran wajib sejak sekolah dasar sebab pada usia kanak-kanak atau yang biasa disebut oleh para ahli psikologi sebagai usia emas (golden age) terbukti sangat menentukan kemampuan anak dalam mengembangkan potensinya". 
Pendidikan karakter yang ditanamkan sejak dini akan membawa pengaruh kepada peserta didik ketika mereka dewasa. Sekolah dasar merupakan tempat paling dasar untuk menanamkan nilai-nilai karakter pada anak-anak. Anak-anak usia sekolah dasar merupakan usia dimana anak-anak mudah menirukan dan mengikuti perilaku yang ada di lingkungan sekitar. Sejalan dengan pendapat (Wibowo, 2012) pembentukan karakter dan kepribadian sangat mudah dibentuk pada karakteristik psikologis anak usia sekolah dasar. Jika nilai-nilai karakter ditanamkan sejak dini maka hal itu dapat dijadikan pondasi bagi peserta didik saat tumbuh dewasa.

Penanam pendidikan karakter di sekolah yang dapat dilakukan guru, seperti mengintegrasikan nilai-nilai karakter ke dalam muatan pembelajaran, keteladanan guru sebagai model atau contoh bagi peserta didik, pembiasaaan lingkungan sekolah yang memiliki karakter baik, pembiasaan seluruh warga sekolah untuk berperilaku sesuai dengan nilai karakter dikembangkan sebagai panutan bagi peserta didik, serta yang terpenting lagi pengembangan budaya sekolah untuk menunjang keberhasilan pendidikan karakter.

Salah satu sekolah yang melaksanakan Penguatan Pendidikan Karakter yaitu SD Negeri Klojen Kota Malang. Berdasarkan wawancara awal dengan kepala sekolah pada tanggal 7 Mei 2018 didapat informasi bahwa SD Negeri Klojen sudah terbiasa menerapkan pendidikan karakter dalam kesehariannya sejak tahun 2009. Saat ini kurikulum yang digunakan di SD Negeri Klojen adalah kurikulum 2013 dengan pendekatan tematik. SD Negeri Klojen melaksanakan program Penguatan Pendidikan Karakter karena merasa semakin hari banyak masalah yang timbul di lingkungan sekolah seperti bullying, sopan santun siswa yang menurun, dan kurangnya sikap sosial siswa terhadap temannya dan masih banyak lagi karena kurang pengawasan dari orang tua yang mayoritas di lingkungan tersebut bekerja menjadi buruh pabrik dan minimnya karakter positif yang dimiliki oleh anak itu sendiri, sehingga kepala sekolah SD Negeri Klojen memutuskan untuk menerapkan Pendidikan karakter dan dimulai dari dalam sekolah. Beliau juga mengatakan bahwa dalam pelaksanaannya program Penguatan Pendidikan Karakter diupayakan melalui kegiatan intrakurikuler dan ekstrakurikuler. Penanaman pendidikan karakter dilaksanakan dengan pembiasaan, mengintegrasi Pendidikan karakter ke dalam muatan mata pelajaran dan keteladaan guru di sekolah sebagai contoh untuk peserta didik. Hal itu dijelaskan juga oleh (Degeng, 2016) bahwa beberapa tanda-tanda era kekinian, seperti ketidakpastian, interpretasi dan pemaknaan yang mengikuti tuntutan zaman, dan argumentasi, silat kata dan perbatahan sebagai pembenaran keputusan.

Penelitian terdahulu juga ada yang membahas tentang pendidikan karakter. Penelitian ini sejalan dengan penelitian tesis yang dilakukan oleh (Handayani, 2018) yang menyatakan: (1) guru harus terus aktif memberikan contoh untuk pembiasaaan peserta didik agar nilai-nilai karakter dapat terealisasikan dengan maksimal; (2) guru memiliki strategi untuk menanamkan pendidikan karakter dalam diri peserta didik melalui pemberian pengetahuan/ wawasan tentang pentingnya nilainilai karakter, guru melakukan pembiasaan dan memberikan contoh untuk penanaman dan pengembangan nilai-nilai karakter sebelum, selama, maupun sesuadah pembelajaran di dalam kelas maupun di luar kelas, guru juga melakukan pembiasaaan halhal yang positif kepada peserta didik, serta guru tidak lupa bekerja sama dengan orang tua peserta didik untuk membantu dalam memantau perkembangan peserta didik selama di rumah.

Sejalan dengan (Hamzah, 2016) Hasil penelitiannya yaitu (1) tujuan pembelajaran yang mengintegrasi pendidikan karakter hanya bersifat administratif, tidak ada kaitanya dengan pembelajaran ataupun hasilnya; (2) secara umum tujuan pembelajaran yang mengintegrasi nilai-nilai karakter sudah mengacu pada pedoman pengembangan kurikulum; (3) terdapat dua karakteristik peserta didik secara umum, yaitu peserta didik yang berkualitas tinggi dan peserta didik yang berkualitas rendah berdasarkan latar belakang social ekonomi di lingkungan sekitar; (5) strategi yang dilakukan dalam pembelajaran adalah ceramah, pengondisian, dan pemberian contoh langsung; (4) strategi pembelajaran menggunakan cara belajar dengan malakukan (learning by doing).Tujuan penelitian ini mendeskripsikan problematika penguatan pendidikan karakter pada rancangan pelaksanaan pembelajaran, pelaksanaan pembelajaran, penilaian pembelajaran dan solusi dari masalah yang terjadi.

\section{METODE}

Penelitian ini menggunakan pendekatan kualitatif karena memberikan uraian atau deskripsi tentang segala hal yang diteliti mengenai rancangan pelaksanaan penelitian, pelaksanaan penelitian, penilaian, dan solusi dari masalah yang dialami guru dalam pengintegrasian penguatan pendidikan karakter dalam pembelajaran tematik. Menurut Menurut (Moleong, 2012) penelitian kualitatif adalah penelitian untuk memahami fenomena tentang yang dialami subjek penelitian misalnya persepsi, perilaku, tindakan, motivasi dll, serta dipaparkan dengan cara holistik, dengan cara deskripsi dalam bentuk kata-kata dan Bahasa pada konteks khusus yang alamiah. Jenis penilitan ini menggunakan jenis studi kasus. Menurut (Yin, 2004) menjelaskan bahwa studi kasus adalah (a) strategi yang cocok digunakan pada penelitian yang pertanyaan pokok berkenaan "bagaimana" dan "mangapa", dan (b) fokus penelitian yang merupakan fenomena kontemporer.

Peran peneliti dalam penelitian kualitatif sebagai instrument kunci (Key Instrumen). Penelitian ini dilakukan dengan hadir secara langsung ke lapangan yang bertempat di SDN Klojen Kota Malang. Peneliti mengamati secara langsung tentang membuatan rancangan pelaksanaan pembelajaran, pelaksanaan pembelajaran, dan penilaian pembelajaran yang mengintegrasikan penguatan pendidikan karakter dalam pembelajaran tematik di kelas IV. 
Lokasi penelitian berada di SDN Klojen Kota Malang yang lebih tepatnya di jalan Parimura No.1 Klojen. Peneliti mengamati secara langsung pada proses pembelajaran yang mengintegrasi penguatan pendidikan karakter dalam pembelaharan tematik di kelas IV. Data dalam penelitian ini menggunakan subjek yaitu guru dan siswa kelas IV A, IVB, IVC. Teknik pengumpulan data menggunakan teknik wawancara, observasi, dan dokumentasi kepada subjek penelitian pada kegiatan pembelajaran yang mengintegrasi penguatan pendidikan karakter dalam pembelajaran tematik di kelas IV.

Analisis data dalam penelitian ini menggunakan (Yin, 2004). Tipe analisis data yang digunkan dalam penelitian adalah berupa analisis holistik, yaitu analisis keseluruhan kasus atau berupa analisis terjalin, yaitu suatu analisis untuk kasus yang spesifik, unik atau ekstrim. penelitian ini menggunakan tiga langkah, yaitu variabel non equivalen sebagai pola, eksplanasi tandingan sebagai pola, dan pola yang lebih sederhana (Expected Out come as a pettern, rival explanations as pettern, and simpler pattern) diadabtasi dari penelitian (Untari, 2016).

\section{HASIL}

Dalam penelitian probelematika, pengeintegrasian penguatan pendidikan karakter ada empat pokok pembahasan, meliputi (1) problem pengintegrasian penguatan pendidikan karakter dalam pembuatan rancangan pelaksanaan pembelajaran, (2) problem dalam pelaksanaan pembelajaran, (3) problem dalam penilaian pembelajaran dan (4) solusi dari masalah yang terjadi.

\section{Problematika Pengintegrasian PPK dalam Rancangan Pelaksanaan Pembelajaran Tematik}

Berdasarkan analisis dokumen RPP yang dibuat guru dalam indikator muatan IPA nilai karakter yang muncul yaitu peserta didik dituntut untuk memiliki rasa ingin tahu setiap materi yang diajarkan contoh materi tentang sumber daya alam, berkewajiban dalam melestarikan sumber daya alam, mengerjakan tugasnya dengan mandiri, bertanggun jawab setiap tugasnya. Nilai karakter dalam muatan IPS kerja sama dalam membuat laporan, memiliki sikap komunikatif dalam menyampaikan pendapat, bertanggung jawab terhadap pekerjaan yang dikerjakan agar cepat selesai. Indikator bahasa Indonesia memiliki nilai karakter seperti memiliki sikap sosial dalam berpendapat ketika berdiskusi, memiliki sikap toleransi, dan demokratis agar ketika berdiskusi diperoleh mufakat yang dapat diterima dari setiap anggota kelompok. Pengintegrasian nilai karakter dalam tujuan pembelajaran sesuai dengan indikator. Nilai karakter yang harus dapat diaplikasikan oleh siswa dan dijadikan sebagai penilai sikap. Nilai karakter yang sudah direncanakan dan harus muncul dalam setiap kegiatan pembalajaran.

Pada langkah-langkah pembelajaran yang terdapat dalam RPP sudah menanamkan nilai-nilai karakter. Nilai karakter yang muncul dalam langkah pengebelajaran yang dibuat yaitu nilai mandiri, komunikatif, religius, toleransi, gotong royong dan demokrasi dalam menyampaikan pendapat. Nilai yang muncul itu merupakan bagian dari lima nilai utama yang ada dalam pendidikan karakter.

Dalam penilaian sikap yang dituliskan oleh guru masih dijadikan satu. Penilaian sikap tidak dipisah pada setiap kegiatan atau seharunya setiap kegiatan memiliki penilaian sikap tersediri. Metode yang digunakan guru masih kurang bervariatif, dalam RPP dituliskan hanya caremah, tanya jawab, berdiskusi dan penugasan. Nilai karakter yang diintegrasikan masih dituliskan secara umum tidak dituliskan, seperti dalam indikator nilai apa yang muncul. Kemudian dalam tujuan pembelajaran seharusnya dituliskan pada setiap tujuan pembelajaran nilai apa yang akan dilaksanakan. Kemudian dalam langkah pembelajaran seharusnya juga diberikan tanda pada setiap kegiatan nilai karakter yang muncul dalam kegiatan tersebut. Hal tersebut memudahkan guru dalam memberikan penilaian dalam setiap kegaitan yang dilakukan.

\section{Problematika Pengintegrasian PPK dalam Pelaksanaan Pembelajaran Tematik}

Berdasarkan hasil observasi terlihat nilai religius dan nasionalis dilakukan sebelum pembelajaran dimulai. Hal tersebut dikarenakan tidak semua materi dapat diintegrasikan dengan nilai nasionalis dan nilai religius. Nilai religius terlihat ketika sebelum pembeljaran dimulai siswa diajak guru untuk berdoa bersama, membaca asmaul husna, membaca surat pendek, mengahafalkan nama rasul. Sementara itu, nilai nasionalisme terlihat ketika sebelum memasuki kelas siswa berbaris terlebih dahulu di depan kelas kemudian bersalaman dengan wali kelas, bernyanyi lagu Indonesia raya, menyanyikan lagu wajib, dan membaca visi dan misi sekolah.

Berdasarkan hasil pengamatan peneliti, guru mengalami kendala terhadap media yang digunakan untuk mengintegrasi penguatan pendidikan karakter. Tidak semua media dapat digunakan untuk penanaman lima nilai karakter yang dianjurkan oleh pemerintah, nilai karakter yang muncul hanya dua dari lima nilai yang disarankan. Contohnya ketika mater jenis pekerjaan siswa diajak untuk wawancara dengan profesi yang ada dilingkungan sekolah, media yang digunakan lingkungan sekitar, hal itu nilai yang muncul dalam kegiatan tersebut yaitu nilai mandiri karena tugas yang dilakukan siswa individu, kemudian nilai integritas jujur dalam apapun hasil dari wawancara tidak dimanipulasi oleh siswa, sopan santun merupakan nilai integritas. Jadi, tidak semua materi dapat diintegrasikan dengan nilai karakter dan tidak semua media juga dapat mengintegrasi lima nilai karakter yang telah diwajibkan oleh pemerintah. 


\section{Promatika Guru Dalam Penilaian Pembelajaran yang Mengintegrasi PPK Tematik}

Berdasarkan hasil wawancara dengan guru, guru mengalami kesulitan dalam menilai sikap siswa karena mengamati setiap tingkah laku siswa membutuhkan waktu yang lama, apalagi ditambah dengan tugas guru yang lain, seperti melakukan penilaian keterampilan dan kognitif siswa. Kurangnya kemampuan guru dalam menguasai alat elektronik modern. Kesulitan dalam mengembangkan intrumen penilaian sikap. Intrumen yang digunakan sesuai dengan yang ada dalam buku guru.

\section{Solusi dalam Problematika Pengintergrasian PPK dalam Pembelajaran Tematik}

Berdasarkan hasil wawancara, kesulitan yang dialami guru dalam pembuatan rancangan pelaksanaan pembelajaran diatasi dengan cara membuat analisis karakter yang muncul sehingga nilai karakter itulah yang harus muncul dalam pelaksanaan pembelajaran. Metode yang digunakan guru seharunya banyak membaca literatur agar bertambah wawasan tentang macam-macam metode yang adam sehingga mampu membuat kelas menjadi aktif dan efektif. Media yang digunakan dalam pelaksanaan pembelajaran bisa menggunakan lingkungan sekitar atau guru bersama siswa dapat membuat media sederhana bersama-sama untuk pembelajaran. Untuk nilai karakter memang tidak bisa dipaksakan harus lima langkah keluar dalam satu materi sehingga guru tidak memaksa semua nilai karakter muncul dalam setiap materi. Solusi terhadap penilaian guru dapat berkomunikasi dengan teman sejawat untuk membuat instrumen penilian sikap yang mudah sehingga semua penilai dapat terselesaikan dengan tepat waktu dan guru tidak memiliki kendala waktu. Selain itu, penilaian dapat dibantu dengan siswa seperti penilaian diri, dan penilaian teman sejawat selain pengamatan dari guru. Guru juga dapat menggunakan buku catatan siswa kegiatan sehari-hari ketika di rumah. Karena di SDN Klojen memiliki tiga buku yang dapat membantu guru dalam melakukan penilaian sikap yaitu buku penghubung, buku harian kegiatan selama di rumah, dan buku pelanggaran yang sangat membantu guru dalam melakukan penilaian.

\section{PEMBAHASAN}

\section{Problematika Pengintegrasian PPK dalam Rancangan Pelaksanaan Pembelajaran Tematik}

Berdasarkan hasil temuan didapat bahwa guru masih menuliskan nilai karakter secara umum dalam rancangan pembuatan pembelajaran. indikator, tujuan pembelajaran dan langkah-langkah pembelajaran belum di tuliskan secara spesifik seperti ditulikan setiap kegiatan menanamkan nilai karakter apa. Hal itu tidak sejalan dengan (Marzuki, 2012) yang menyatakan bahwa dalam penyusunan RPP yang mengintegrasi PPK harus direvisi dengan cara; (1) rumusan tujuan pembelajaran selain mengembangkan kemampuan kognitif dan psikomotor juga harus di tambahkan satu tujuan pembelajaran yang khusu untuk karakter; (2) metode yang dipilih tidak hanya memikirkan untuk mengembangkan kemampuan kognitif dan psikomotor, tetapi untuk mengembangkan nilai karakter siswa; (3) kegiatan pendahuluan harus direvisi ditambahkan dengan nilai karakter yang nampak pada setiap kegiatan; (4) dalam revisi teknik penilaian guru dapat mengubah/ menambahkan teknik penilaian sehingga teknik penilaian tersebut dapat mengukur pencapaian peserta didik dalam kompetensi dan karakter.

Berdasarkan hasil temuan dari pembuatan rancangan pelaksanaan yang dibuat guru peneliti merasa belum begitu tata dan belum begitu terlihat nilai karakter. Hal tersebut tidak sejalan dengan menurut (Degeng, 2013, 2017) yang menyatakan bahwa kagiatan pengelolahan pembelajaran adalah gagasan-gagasan pokok tentang kegiatan pembelajaran yang akan dijadikan sebagai pedoman untuk tercapainya tujuan pembelajaran, memang seharunya belajar dan pembelajaran didesain menggunakan pendekatan keteraturan. Jadi, dapat disimpulkan jika sebuah rancangan pelaksanaan pembelajaran tidak tersusun dengan benar, maka tujuan pembelajaran tidak dapat tersampaikan dengan baik.

\section{Problematika Pengintegrasian PPK dalam Pelaksanaan Pembelajaran Tematik}

Berdasarkan hasil temuan dalam kegiatan inti, guru memberikan apresiasi kepada peserta didik. Apresiasi tersebut berupa apresiasi verbal, maupun guru dapat memberikan pengahargaan dengan membuat sendiri, seperti berupa bintang. Hal tersebut dapat membuat pembelajaran menjadi menyenangkan dan membuat siswa menjadi aktif. Pemberian apresiasi/ penghargaan dapat meningkatkan kreativitas siswa berkembang. Sehingga dengan mudah guru dapat mengembangkan segala potensi dan kemampuan yang dimiliki oleh siswa. Suasana kelas seperti itu yang dapat mendukung keterlaksanaan pendidikan karakter pada siswa. Hasil analisis tersebut sejalan dengan pendapat (Degeng, 1998; Hidayatullah, 2010) bahwa strategi dalam pendidikan karakter dapat dilakukan melalui beberapa sikap, salah satunya yaitu menciptakan suasana belajar yang kondusif agar siswa betah memperoleh kenikmatan dalam belajar.

Guru juga menggambarkan pembiasaan karakter tertentu seperti melakukan sholat tepat waktu. Hal itu terlihat ketika guru menghentikan pembelajaran, walaupun waktu istirahat kedua belum tiba. Guru melaksanakan hal tersebut agar siswa terbiasa melakukan ibadah sholat tepat waktu. Saat guru masih melaksanakan pembelajaran, siswa mengingatkan guru bahwa untuk sholat sudah dekat. Hal ini menunjukkan bahawa siswa sudah terbiasa untuk melakukan sholat berjamaah disekolah dengan tepat waktu. Pembiasaan yang dilakukan guru dan siswa tersebut sesuai dengan pernyatan oleh (Fadlillah \& Khirida, 2013) bahwa metode pembiasaan sikap sangat efektif digunakan karena akan melatih kebiasaan-kebiasaan yang baik kepada peserta didik sejak dini. 
Pada proses pembelajaran guru selalu mengingatkan secara spontan tentang nilai-nilai karakter, seperti mengingatkan sikap berdoa harus dengan khidmat, ketika ulangan tidak boleh mencontek. Hal itu sepaham dengan (Wibowo, 2012) menjelaskan bahwa salah satu model pengintegrasian PPK di sekolah adalah program pengembangan diri berupa kegiatan spontan yang dilakukan pada saat itu juga. Guru perlu melakukan kegiatan spontan tersebut ketika siswa tidak mengetahui kesalahan yang telah dilakukan. Hal itu akan memberikan dampak tersendiri sehingga siswa tidak mengulangi kesalahan itu kembali.

Berdasarkan hasil temuan guru metode yang digunakan guru masih metode ceramah, penugasan, tanya jawab, dan diskusi. Hal itu belum dapat dikatakan dapat membuat siswa menjadi aktif. Hal itu tidak sejalan dengan pernyataan (Agung, 2017) peran guru dalam PPK menjadi fasilitator yang mengusahakan menjadi memfasilitasi, menawarkan, menyediakan dan membantu dalam pembelajaran PPK yang bersikap aktif, partisipatif, dan kolaboratif. Aktif maksudnya siswa dapat menjalankan pembelajaran dnegan dinamis, giat dan bergairah. Pastisipatif maksudnya siswa mampu terlibat langsung dalam pembelajaran secara sukarela, menyenangkan, sedangkan kolaboratif maksudnya mampu membangun kerja sama dan kebersamaan guna mencapai tujuan bersama.

\section{Problematika Guru dalam Penilaian Pembelajaran yang Mengintegrasi PPK Tematik}

Berdasarkan hasil temuan peneliti diketemukan bahwa guru mengalami kesulitan dalam penilaian. Guru dibutuhkan waktu yang banyak untuk mengamati setiap tinglah laku peserta didik. Selain itu penilaian yang digunakan guru masih mengikuti intrumen dari buku guru. Hal itu tidak sejalan dengan pendapat (Marzuki, 2012) untuk menilai pendidikan karakter banyak yang ditawarkan, intrumen yang digunakan harulah dilengkapi dengan rubrik penilaian untuk menghindari subjektif, baik dalam bentuk instrumen penilaian pengamatan (lembar pengamatan) maupun instrumen penilaian skala sikap. Kendala guru dalam kerkurangan waktu untuk menilai peserta didik juga oleh penelitian (Fitria, 2017) yang menyatakan bahwa untuk teknik observasi guru serigkali merasa kekurangan waktu dalam menilai sikap siswa karena harus mengamati dan menilai setiap sikap siswanya satu per satu.

\section{Solusi dalam Problematika Pengintergrasian PPK dalam Pembelajaran Tematik}

Berdasarkan kendala yang diketemukan solusi yang dilakukan untuk mengatasi agar penanaman pendidikan karakter dapat tercapai secara maksmal, dibutuhkan kerja sama semua pihak. Tidak hanya pihak sekolah yang mengusahakan agar penanaman karakter dapat berjalan dengan maksimal. Hal itu sejalan dengan pernyataan dari (Saptono, 2011) yang menyatakan bahwa faktor keberhasilan pendidikan karakter tidak hanya ditentukan dari pihak sekolah, tetapi lingkungan rumah dan masyarakat juga harus ikut andil membantu dalam keberhasilan pendidikan karakter. sekolah harus mampu mendorong seluruh perangkat sekolah untuk membangun dan mewujudkan pendidikan karakter. selain itu aparatur pemangku Pendidikan, seperti dinas pendidikan harus terus membantu dan mengevaluasi berjalannya pendidikan karakter di setiap sekolah, memberikan bimbingan tentang pembuatan RPP, memberikan sarana prasarana untuk keberhasilan penanaman pendidikan karakter

Selain itu, menurut (Wibowo, 2012), supaya penerapan pendidikan karakter dapat berhasil di sekolah, ada beberapa hal yang harus dipenuhi, yaitu (1) karyawan, guru, pimpinan sekolah, dan pemangku kebijakan sekolah harus mampu memberikan cerminan untuk peserta didik; (2) pendidikan harus dilakukan di sekolah secara terus menerus atau konsisten supaya menjadi pembiasaan; (3) yang terkhir penanaman nilai-nilai karakter. Guru mengalami kendala dalam penilaian dikarena membutuhkan waktu yang lama untuk melakukan penilaian, sep erti observasi, dan dibutuhkan ketelitian dalam melakukan memasukan penilaian seperti penilaian antar teman dan penilaian diri, sebab jika tidak teliti maka penialian bias dianggap tidak akuran. Solusi untuk mengatais kendala penilaian guru dapat bekerja sama dengan siswa dalam membantu melakukan penilaian seperti guru dapat mengolah nilai sikap dari catatan harian siswa dan catatan pelanggaran siswa. Hal tersebut sejalan dengan penelitian yang dilakukan (Ginanjar, 2015) sebelum kegiatan pembelajaran guru dapat melakukan kesepakatan dengan siswa menganai punishment bagi siswa yang melanggar dan tidak taat pada aturan, selanjutnya meminta siswa mengusulkan hukuman yang akan diterapkan, setelah terkumpul guru dan siswa menyaring hukuman yang pas untuk dilaksanakan dan kesepakatan menentukan hukuman yang sekiranya mendidik.

\section{SIMPULAN}

Sekolah sebagai tempat pertumbuhan dan perkembangan peserta didik juga sebagai tempat yang tepat dalam menanmkan nilai karakter khususnya mulai tingkat sekolah dasar. Dalam menanamkan nilai karater tentunya sekolah juga perlu merencanakan, melaksanakan, serta mengevaluasi terkait implementasi pengintegrasian PPK di dalam kelam melalui pembelajaran tematik. Berdasarkan penelitian yang telah dilakukan dapat disimpulkan bahwa dalam pengintegrasian PPK ke dalam pembelajaran tematik belum berjalan dengan maksimal karena dalam pembuatan rancangan pelaksanaan pembelajaran, pelaksanaan dan evaluasi, masih terdapat kendala. Secara rinci dapat disimpulkan sebagai berikut. Pertama, kendala yang dihadapi guru dalam pengintegrasian PPK pada pembalajaran tematik. Analisi kegiatan pembelajaran yang mengintegrasi nilainilai karakter. metode yang guru belum bervariatif. Kendala yang lain yaitu proses penilain sikap peserta didik yang membutuhkan waktu yang cukup banyak dengan metode penilian yang bervariatif. Kendala yang terakhir adalah faktor dari masyarakat dan kelaurga yang kurang mendukung untuk pendidikan karakter di sekolah atau di lingkungan rumah tempat 
tinggal peserta didik. Kedua, solusi dari kendala yang dihadapi guru untuk mengoptimalkan penanaman pendidikan karakter dengan saling bekerja sama antara pihak sekolah, masyarakat, dinas pendidikan, dan jika dibutuhkan juga konselor untuk menangan anak-anak yang memiliki sikap lebih. Serta dibutuhkan evaluasi jika untuk memperbaiki kekurangan dalam menanamkan pendidikan karakter.

Berdasarkan hasil dari penelitian ini, terdapat beberapa saran dan masukan dari peneliti untuk sekolah, guru maupun peneliti selanjutnya terkait dengan pengintegrasian PPK dalam pembelajaran tematik di kelas IV. Uraian saran dari peneliti dijelaskan sebagai berikut. Pertama, pelatihan tentang pendidikan karakter untuk meningkatkan kemampuan guru dalam pelaksanaan pengintegrasian penguatan pendidikan karakter dalam pembelajaran tematik di sekolah dasar yang dimonitoring oleh kepala sekolah hendaknya tetap dilaksanakan. Kedua, mengoptimalkan dalam pembuatan rancangan pelaksanaan pembelajaran yang dibuat oleh guru, untuk mengetahui adanya pengembangan pendidikan karakter dalam RPP yang disesuaikan dengan muatan materi yang akan dipelajari. Ketiga, guru harus mampu menciptakan suasana belajar yang bermakna bagi siswa, seperti pembalajaran yang menggunakan media pembelajaran bervariatif, metode pembelajaran yang bervariatif hendaknya lebih dioptimalkan. Keempat, evaluasi yang dilakukan guru setiap hari harus dimaksimalkan agar pengintegrasian penguatan pendidikan karakter terlaksana dengan baik dan dapat mencapai tujuan yang diinginkan. Kelima, sekolah melakukan kerja sama dengan pihak keluarga dan masyarakat dengan cara menjadwalkan pertemuan secara rutin untuk memberikan arahan dan bimbingan guna mendukung pelaksanaan pendidikan karakter di lingkungan rumah dan sekolah.

\section{DAFTAR RUJUKAN}

Agung, I. (2017). Peran Fasilitator Guru Dalam Penguatan Pendidikan Karakter (PPK). Perspektif Ilmu Pendidikan, 31 (2), 106119. https://doi.org/10.21009/PIP.312.6

Degeng, N. S. (2013). Ilmu Pembelajaran Klasifikasi Variabel untuk Pengembangan Teori dan Penelitian. Bandung: Kalam Hidup.

Degeng, N. S. (2016). Sendi Pendidikan Karakter Orkestra Hubungan Antarmanusia di Tengah Keberagaman Bahasa Cinta. 1-6. http://pasca.um.ac.id/conferences/index.php/gtk/article/view/167/156

Degeng, N. S. (2017). Revolusi Mental Dalam Belajar dan Pembelajaran. Kapita Selekta Karya Ilmiah Dosen Pascasarjana Universitas Negeri Malang, 1-17. http://pasca.um.ac.id/conferences/index.php/kskid/article/download/638/322

Fadlillah, M \& Khirida, M. L. (2013). Pendidikan Karakter Anak Usia Dini: Konsep \& Aplikasinya dalam PAUD. Yogyakarta: Ar Ruzz.

Fitria, M. Z. (2017). Pelaksanaan Penilaian Sikap Siswa pada Kurikulum 2013 Kelas I di SD Negeri 1 Tanjung Boyolali. -, 01, 1-7. http://eprints.ums.ac.id/54218/1/NASKAH PUBLIKASI.pdf

Ghufron, A. (2007). Integrasi nilai-nilai karakter bangsa pada kegiatan pembelajaran. Cakrawala Pendidikan, 13-24. http://journal.uny.ac.id/index.php/article/viewFile/230/pdf

Ginanjar, W. (2015). Implementasi Kurikulum 2013 tentang Penilaian Sikap Siswa Kelas 1 SD HJ. Isriati Baiturrahman 1 Semarang Tahun Ajaran 2015/2016. http://eprints.walisongo.ac.id/5351/1/113911010.pdf

Hamzah, A. (2016). Profil Pembelajaran Karakter di Sekolah Dasar. JINOTEP, (6), 302. http://journal2.um.ac.id/index.php/jinotep/article/viewFile/2341/1406

Handayani, E. R. (2018). Internalisasi Nilai-Nilai Karakter di SDN 1 Dono Kecamatan Sendang Kabupaten Tulungagung. Tesis tidak diterbitkan. Universitas Negeri Malang, Malang.

Hidayatullah, F. (2010). Pendidikan Karakter: Membangun Peradaban Bangsa. Surakarta: Yuma Pustaka.

Johansson, D. (2011). Practies for teaching moral velues in the early year: A call for a pedagogy of participation. 6, $109-124$. https://www.researchgate.net/publication/254091165_Practices_for_teaching_moral_values_in_the_early_years_A_call_f or_a_pedagogy_of_participation/download

Julaiha, S. (2014). Implementasi Pendidikan Karakter dalam Pembelajaran. Dinamika Ilmu, 14(2), $226-239$. http://journal.iainsamarinda.ac.id/index.php/dinamika_ilmu/acticle/view/15/pdf_16.

Marzuki. (2012). Pengintegrasian Pendidikan Karakter dalam Pembelajaran di Sekolah. Jurnal Pendidikan Karakter, 2(1), 3344. https://media.neliti.com/media/publications/122370-ID-pengintegrasian-pendidikan-karakter-dala.pdf

Moleong, J. L. (2012). Metode Penelitian Kualitatif. Bandung: Remaja Rosda Karya.

Saptono. (2011). Dimensi-Dimensi Pendidikan Karakter: Wawasan, Strategi, dan Langkah Praktis. Bandung: Penerbit Erlangga.

Suwandayani, B. I., \& Isbadrianingtyas, N. (2017). Peran Budaya Sekolah dalam Pembentukan Karakter Anak Sekolah Dasar. SENASGABUD, 34-41. http://research-report.umm.ac.id/index.php/SENASGABUD

Untari, S. (2016). Public-Private Partnerships in Improving the Quality of Education for the Poor in Indonesia. Public Policy and Administration Research, 6(6), 65-72. https://www.iiste.org/Journals/index.php/PPAR/article/view/31414

Wibowo, A. (2012). Pendidikan Karakter: Strategi Membangun Karakter Bangsa Berperadaban. Yogyakarta: Pustaka Belajar.

Yin, R. K. (2004). Studi Kasus: Desain dan Metode. Jakarta: Raja Grafindo Persada. 